\title{
Enlarged lantern size in similar-sized, sympatric, sibling species of Strongylocentrotid sea urchins: from phenotypic accommodation to functional adaptation for durophagy
}

\author{
Nils T. Hagen
}

Received: 15 May 2007 / Accepted: 31 October 2007/Published online: 23 November 2007

(C) The Author(s) 2007

\begin{abstract}
Strongylocentrotus droebachiensis is a well known omnivorous sea urchin with an unrivalled capacity to destroy North Atlantic kelp forests. S. pallidus is a lesser known, morphologically similar, and closely related species with no record of destructive grazing, despite its larger lantern size. I quantify the lantern size of both species using bivariate allometric analysis, and test the hypothesis that enlarged lantern size facilitates durophagy, the consumption of hard prey, by measuring the feeding capacity of urchins with different lantern sizes when offered a hard-shelled prey, the blue mussel, Mytilus edulis. The results suggest that $S$. droebachiensis has a limited capacity for durophagous feeding irrespective of lantern size, whereas in S. pallidus the ability to exploit hard shelled prey is positively related to lantern size. This is apparently the first evidence of a relationship between trophic morphology and diet in regular sea urchins. The hypothesis of systematic latitudinal variation in the lantern size of $S$. pallidus is reappraised and rejected. $S$. droebachiensis had larger gonads than S. pallidus in field samples, confirming that its small lantern is not impeding nutrient acquisition in shallow habitats.
\end{abstract}

\section{Introduction}

The congeneric sea urchins Strongylocentrotus droebachiensis and S. pallidus are ideal candidates for the study of

Communicated by M. Kühl.

N. T. Hagen $(\bowtie)$

Department of Fisheries and Natural Science,

Bodø University College, 8049 Bodø, Norway

e-mail: Nils.Hagen@hibo.no how divergent evolution leads to minor adaptations with major ecological consequences. These closely related (Biermann et al. 2003), morphologically similar species (Vasseur 1951; Swan 1962; Jensen 1974; Gagnon and Gilkinson 1994) are the only representatives of the sea urchin genus Strongylocentrotus in the Atlantic Ocean. Yet their ecological impact is remarkably different. S. droebachiensis is notorious for its unrivalled ability to reduce primary productivity and coastal biodiversity through widespread overgrazing of kelp forests (Hagen 1983; Chapman and Johnson 1990; Scheibling and Hatcher 2007), whereas $S$. pallidus, although sympatric throughout most of the Arctic-boreal distributional range, is more reclusive and occurs further to the north, at much lower densities, or in deeper habitats (Jensen 1974; Gilkinson et al. 1988; Bluhm et al. 1998).

S. droebachiensis and S. pallidus are the most recently diverged species pair in the genus Strongylocentrotus. They diverged 2.1-3.1 million years ago (Lee 2003; Dayal et al. 2004), but the separation from their closest relative $S$. purpuratus occurred during an earlier burst of Strongylocentrotid speciation in the North Pacific (Palumbi and Kessing 1991; Biermann et al. 2003), coinciding with the initial opening of the Bering Strait about 5 million years ago (Marincovich and Gladenkov 1999). They, or their common ancestor, subsequently invaded the North Atlantic as part of a major influx of species referred to as the trans-Arctic interchange (Vermeij 1991). It is noteworthy, as a preamble to the current ecological situation, that the evolution of Strongylocentrotid sea urchins in the North Pacific paralleled the evolution of their principal food source, the large brown algae known as kelp (Estes and Steinberg 1988), which also invaded the North Atlantic during the trans-Arctic interchange (Vermeij 1992). 
The ecological relationship between kelp and the Strongylocentrotid sea urchins ranges from kelp-dominated coexistence, to overgrazing followed by perpetuation of kelp-less, urchin-dominated barren grounds where the urchins persist relatively unimpeded under severe self-inflicted food limitation (Harrold and Pearse 1987). Resource acquisition under this extreme range of food availability is facilitated by the functional flexibility of the urchins' unique feeding apparatus, the Aristotle's lantern. This versatile and structurally complex organ is adapted for a general, omnivorous diet including soft sediments, hard calcified surfaces, and a wide array of plant and animal prey (De Ridder and Lawrence 1982).

The hypothesis that overall feeding capacity is directly related to, and limited by, lantern size is widely inferred (Lawrence 1987), as there is little evidence of structural or functional specialization of the lantern beyond " ... an evolutionary progression towards a stronger, more efficient feeding apparatus for a general diet" (Lawrence 1975, p. 240). Lawrence et al. (1995) accordingly suggested that $S$. franciscanus, the largest member of the genus, owes its great size to an unusually large lantern, which presumably facilitates higher feeding rates and greater organic production. In $S$. pallidus, however, enlarged lantern size relative to $S$. droebachiensis (Vasseur 1951), is still a puzzling phenomenon (Gagnon and Gilkinson 1994), evidently not associated with larger maximum size (Jensen 1974), differences in growth rate (Vader et al. 1986), or greater organic production (Bluhm et al. 1998).

Some species, including $S$. purpuratus, respond to food limitation by enlarging lantern size through plastic allocation of resources from body growth to lantern growth (Ebert 1980, 1996; Russell 1987; Edwards and Ebert 1991), but the lantern size of $S$. droebachiensis is so similar in different sampling locations (c.f. Vasseur 1952; Russell 2001), that the notion of phenotypic plasticity has been rejected by Lawrence et al. (1998). The only test of the associated hypothesis, that environmentally induced enlarged lantern size facilitates acquisition of scarce food, is provided by Black et al. (1984), who found a positive correlation between enlarged lantern size and feeding capacity in the Australian urchin Echinometra mathaei. The results were not unequivocal, however, as urchins with smaller lanterns actually consumed 7.2 times more of the sea lettuce Ulva lactuca, and 2.8 times more of the kelp Ecklonia radiata, arguably the two best food items offered in their laboratory experiment (Black et al. 1984, Table IX), while urchins with larger lanterns consumed 2.9 times more of the calcified red algae Metagonolithium sp. A reinterpretation of these results is consistent with the hypothesis that urchins with small lanterns are superior consumers of high quality soft food, and conversely that enlarged lantern size facilitates durophagy, the consumption of hard prey.

In this study, I test the hypothesis that enlarged lantern size is a functional adaptation for durophagy by measuring the feeding capacity of urchins with different lantern sizes when offered a hard-shelled prey, the blue mussel, Mytilus edulis. Using bivariate allometric analysis (Warton et al. 2006), I quantify and compare the relative lantern sizes of $S$. droebachiensis and $S$. pallidus from Bodø, Northern Norway, to address the hypothesis of systematic latitudinal variation in the lantern size of S. pallidus (Vasseur 1952). I also examine the relationship between gonad size and lantern size in field populations in light of the urchins' durophagous feeding capacity. Finally, I reassess published data for lantern size variation in $S$. purpuratus and S. franciscanus and give a tentative interpretation of the role of lantern size in the speciation of $S$. droebachiencis and S. pallidus.

\section{Materials and methods}

\section{Allometric analysis}

\section{Sampling}

Morphometric data for the allometric analysis were obtained by dissecting 80 individuals of S. droebachiensis and 79 individuals of $S$. pallidus from two sampling locations in Bodø, northern Norway. The first sample was obtained from a tidal channel named Godøystraumen in February 2006 (67 $14^{\prime} 20^{\prime \prime} \mathrm{N}, 14^{\circ} 43^{\prime} \mathrm{E}$; c.f. Hagen 1987), prior to the annual spawning season (Vasseur 1952; Falk-Pettersen and Lønning 1983), and the second sample was obtained 6 months later, in August, in Mørkvedbukta (67 $\left.14^{\prime} 30^{\prime \prime} \mathrm{N}, 14^{\circ} 34^{\prime} \mathrm{E}\right)$, a small exposed bay next to the Marine Research Station of Bodø University College. Both samples were collected by SCUBA diving in overgrazed areas surrounded by scattered

Table 1 Estimates of measurement error in demipyramid length, test diameter and wet body mass of Strongylocentrotus pallidus, and S. droebachiensis, from Bod $\varnothing$, Norway

\begin{tabular}{lrrll}
\hline Variable & $N$ & $n_{i}$ & $\delta$ & $s^{2}$ \\
\hline Ln(Demipyramid Length) & 159 & 3 & 0.00045 & 0.01575 \\
Ln(Test Diameter) & 159 & & & 0.01832 \\
Initial error estimate & 8 & 5 & 0.00058 & \\
Second error estimate & 60 & 5 & 0.00031 & \\
Ln(Wet Body Mass) & 159 & & & 0.16608 \\
Initial error estimate & 8 & 5 & 0.00176 & \\
Second error estimate & 60 & 5 & 0.00004 & \\
\hline
\end{tabular}

$N$ number of individuals; $n_{i}$ number of repeat measurements; $\delta$ measurement error; $s^{2}$ sample variance 
patches of intact kelp. There was no significant effect of location in preliminary allometric analyses of relative lantern size (SMA, $P>0.05$; c.f. Warton et al. 2006), and data from the two locations were pooled in subsequent analyses.
All measurements of mass were recorded with an accuracy of $0.01 \mathrm{~g}$ using laboratory scales, and all measurements of length were recorded with an accuracy of $0.01 \mathrm{~mm}$ using electronic calipers. Prior to dissection

Table 2 Effect of measurement error on allometric analysis of the relationship between test diameter $(X)$ and demipyramid length $(Y)$ of Strongylocentrotus pallidus, and S. droebachiensis, from Bod $\emptyset$, Norway

\begin{tabular}{|c|c|c|c|c|c|c|}
\hline Group & $N$ & $r^{2}$ & $P$ & $\beta$ & $\operatorname{Ln}(\alpha)$ & $\alpha$ \\
\hline S. droebachiensis & 80 & 0.807 & 0.000 & $0.9714(0.8801,1.0723)$ & $-1.495(-1.869,-1.121)$ & 0.2242 \\
\hline S. pallidus & 79 & 0.627 & 0.000 & $0.9918(0.8638,1.1389)$ & $-1.422(-1.944,-0.944)$ & 0.2412 \\
\hline \multicolumn{7}{|l|}{ Isometry } \\
\hline S. droebachiensis & & & 0.561 & 1 & & \\
\hline S. pallidus & & & 0.907 & 1 & & \\
\hline Common slope & & & 0.810 & $0.9783(0.9031,1.0598)$ & & \\
\hline Common elevation & & & 0.000 & & & \\
\hline S. droebachiensis & & & & & -1.522 & 0.2183 \\
\hline S. pallidus & & & & & -1.371 & 0.2539 \\
\hline \multicolumn{7}{|c|}{$\begin{array}{l}\text { Analysis including estimates of measurement error: } \\
\quad \delta_{\ln (\text { Test Diameter })}=0.00576, \delta_{\ln (\text { Demipyramid Length })}=0.00045\end{array}$} \\
\hline S. droebachiensis & 80 & 0.852 & 0.000 & $0.9740(0.8932,1.0621)$ & $-1.505(-1.834,-1.176)$ & 0.2220 \\
\hline S. pallidus & 79 & 0.685 & 0.000 & $0.9972(0.8782,1.1323)$ & $-1.443(-1.924,-0.961)$ & 0.2362 \\
\hline \multicolumn{7}{|l|}{ Isometry } \\
\hline S. droebachiensis & & & 0.547 & 1 & & \\
\hline S. pallidus & & & 0.965 & 1 & & \\
\hline Common slope & & & 0.793 & $0.9813(0.9139,1.0539)$ & & \\
\hline Common elevation & & & 0.000 & & & \\
\hline S. droebachiensis & & & & & -1.534 & 0.2157 \\
\hline S. pallidus & & & & & -1.382 & 0.2511 \\
\hline
\end{tabular}

95\% confidence limits for slope and intercept in parentheses

$N$ number of individuals; $r^{2}$ coefficient of determination; $P$ probability value; $\beta$ slope of SMA-line; $\operatorname{Ln}(\alpha)$ intercept of SMA-line; $\alpha$ constant of allometric equation

Table 3 Durophagous feeding experiments with small and large sea urchins, Strongylocentrotus pallidus and S. droebachiensis, using the blue mussel, Mytilus edulis, as prey

Date, duration and number of replicate urchins

\begin{tabular}{|c|c|c|c|c|c|c|c|}
\hline \multirow[t]{2}{*}{ Date } & \multirow{2}{*}{$\begin{array}{l}\text { Duration } \\
\text { (days) }\end{array}$} & \multirow{2}{*}{$\begin{array}{l}\text { M. edulis } \\
\text { Size } \\
(\mathrm{mm})\end{array}$} & \multicolumn{2}{|c|}{ S. droebachiensis } & \multicolumn{2}{|c|}{ S. pallidus } & \multirow[t]{2}{*}{ Sum } \\
\hline & & & Small & Large & Small & Large & \\
\hline \multirow[t]{3}{*}{ Dec. 172005} & 2.7 & $10 \pm 2.5$ & 3 & 3 & & & 6 \\
\hline & & $20 \pm 2.5$ & 3 & 3 & & & 6 \\
\hline & & $30 \pm 2.5$ & 3 & 3 & & & 6 \\
\hline \multirow[t]{3}{*}{ Dec. 302005} & 3.7 & $10 \pm 2.5$ & 6 & 6 & & & 12 \\
\hline & & $20 \pm 2.5$ & 6 & 6 & & & 12 \\
\hline & & $30 \pm 2.5$ & 6 & 6 & & & 12 \\
\hline \multirow[t]{3}{*}{ Jan. 132006} & 3.7 & $10 \pm 2.5$ & & & 6 & 6 & 12 \\
\hline & & $20 \pm 2.5$ & & & 6 & 6 & 12 \\
\hline & & $30 \pm 2.5$ & & & 6 & 6 & 12 \\
\hline \multirow[t]{3}{*}{ Feb. 242006} & 3.7 & $10 \pm 2.5$ & 6 & 6 & 6 & 6 & 24 \\
\hline & & $20 \pm 2.5$ & 6 & 6 & 6 & 6 & 24 \\
\hline & & $30 \pm 2.5$ & 6 & 6 & 6 & 6 & 24 \\
\hline \multirow[t]{2}{*}{ Jun. 152006} & 3.7 & $25 \pm 2.5$ & 3 & 3 & 3 & 3 & 12 \\
\hline & & $35 \pm 2.5$ & 3 & 3 & 3 & 3 & 12 \\
\hline Total & & & 51 & 51 & 42 & 42 & 186 \\
\hline
\end{tabular}


Table 4 Allometric analysis of the relationship between urchin size and Aristotle's lantern size of Strongylocentrotus pallidus and S. droebachiensis, from Bodø, Norway

\begin{tabular}{|c|c|c|c|c|c|c|c|}
\hline$\overline{\text { Group }}$ & $N$ & $r^{2}$ & $P$ & $\beta$ & $\operatorname{Ln}(\alpha)$ & $\alpha$ & $\alpha$-ratio \\
\hline \multicolumn{8}{|l|}{$X$ : Test diameter } \\
\hline$Y$ : Wet lantern mass & & & 0.393 & $2.650(2.452,2.865)$ & & & \\
\hline S. droebachiensis & 80 & 0.829 & 0.000 & & -9.816 & 0.000055 & 0.60 \\
\hline S. pallidus & 79 & 0.610 & & & -9.299 & 0.000092 & 1.68 \\
\hline$Y:$ Lantern dry mass & & & 0.211 & $2.565(2.386,2.760)$ & & & \\
\hline S. droebachiensis & 80 & 0.852 & 0.000 & & -10.032 & 0.000044 & 0.57 \\
\hline S. pallidus & 79 & 0.665 & & & -9.469 & 0.000077 & 1.76 \\
\hline$Y$ : Lantern calcite & & & 0.216 & $2.689(2.496,2.899)$ & & & \\
\hline S. droebachiensis & 80 & 0.839 & 0.000 & & -10.646 & 0.000024 & 0.55 \\
\hline S. pallidus & 79 & 0.662 & & & -10.057 & 0.000043 & 1.80 \\
\hline$Y:$ Lantern calcite-free dry mass & & & 0.336 & $2.291(2.046,2.566)$ & & & \\
\hline S. droebachiensis & 80 & 0.581 & 0.000 & & -11.076 & 0.000015 & 0.64 \\
\hline S. pallidus & 79 & 0.368 & & & -10.635 & 0.000024 & 1.55 \\
\hline \multicolumn{8}{|l|}{$X$ : Wet body mass } \\
\hline$Y$ : Wet lantern mass & & & 0.269 & $0.911(0.846,0.981)$ & & & \\
\hline S. droebachiensis & 80 & 0.850 & 0.000 & & -3.068 & 0.047 & 0.56 \\
\hline S. pallidus & 76 & 0.640 & & & -2.490 & 0.083 & 1.78 \\
\hline$Y:$ Lantern dry mass & & & 0.123 & $0.880(0.821,0.944)$ & & & \\
\hline S. droebachiensis & 80 & 0.870 & & & -3.493 & 0.030 & 0.54 \\
\hline S. pallidus & 76 & 0.685 & & & -2.873 & 0.057 & 1.86 \\
\hline Y: Lantern calcite & & & 0.148 & $0.923(0.859,0.992)$ & & & \\
\hline S. droebachiensis & 80 & 0.855 & 0.000 & & -3.792 & 0.023 & 0.52 \\
\hline S. pallidus & 76 & 0.682 & & & -3.143 & 0.043 & 1.91 \\
\hline$Y:$ Lantern calcite-free dry mass & & & 0.241 & $0.789(0.707,0.882)$ & & & \\
\hline S. droebachiensis & 80 & 0.617 & 0.000 & & -5.250 & 0.005 & 0.61 \\
\hline S. pallidus & 76 & 0.393 & & & -4.759 & 0.009 & 1.63 \\
\hline \multicolumn{8}{|l|}{$X$ : Lantern dry mass } \\
\hline$Y:$ Lantern calcite-free dry mass & & & 0.903 & $0.885(0.801,0.979)$ & & & \\
\hline S. droebachiensis & 80 & 0.637 & 0.08 & & -2.118 & 0.120 & 1.06 \\
\hline S. pallidus & 79 & 0.562 & & & -2.177 & 0.113 & 0.94 \\
\hline
\end{tabular}

The slope and elevation of the logarithmic allometric equation, $\ln (Y)=\ln (\alpha)+\beta \ln (X)$, were determined using standardized major axis (SMA) estimation. $95 \%$ confidence limits for slope in parentheses

$N$ number of individuals; $r^{2}$ coefficient of determination; $P$ probability value; $\beta$ slope of SMA-line; $\operatorname{Ln}(\alpha)$ intercept of SMA-line; $\alpha$ constant of allometric equation; $\alpha$-ratio: multiplicative difference in lantern size when there is a common slope and significant shift in elevation between the two species

the wet mass, test diameter, and test height were determined. Following dissection, measurements were obtained of gonad wet mass, lantern wet mass, lantern height, and lantern diameter. Lantern dry mass was determined after $\approx 24 \mathrm{~h}$ drying in a $105^{\circ} \mathrm{C}$ oven. Organic matter was removed from the lantern by $\approx 48 \mathrm{~h}$ submersion in a $3 \mathrm{Mol}$ solution of $\mathrm{NaOH}$, and the combined calcite mass of the lantern ossicles was determined after rinsing in fresh water and air drying. Lantern calcite free dry mass was estimated as the difference between combined calcite mass of the lantern ossicles and lantern dry mass. Demipyramid length was determined by measuring the distance between the tip and the epiphysis junction for three demipyramids from each lantern (Ebert 1980).

\section{Allometric equation}

The relationship between body size and lantern size was analysed using the general allometric equation (Ebert 1988; Reiss 1991): 
$Y=\alpha X^{\beta}$.

After logarithmic transformation the relationship becomes linear:

$\ln (Y)=\ln (\alpha)+\beta \ln (X)$.

Slopes and elevations of the linear equation (2) were estimated and compared using standardised major axis (SMA) estimation, the preferred choice in current bivariate linefitting methods for allometry (Falster et al. 2006; Warton et al. 2006). Unlike ordinary least squares (OLS) regression, the SMA relation is symmetrical (Ricker 1984), i.e. insensitive to the choice of body size or lantern size as $X$ or $Y$, but the method requires a posteriori assessment of the magnitude of measurement error in both variables and its overall effect on the outcome of the analysis (Warton et al. 2006).

\section{Measurement error}

Estimates of measurement error were calculated according to Warton et al. (2006, p. 283, Eqs. 31, 34, Example 4). For demipyramid length measurement error was estimated from repeated measurements of three demipyramids from the lantern of each of the 159 urchins in the entire sample. The estimated value, 0.00045 , is small compared to the value of the sample variance, $S_{\ln (\text { Demipyramid }}^{2}$ Length) $=$ 0.01575 (Table 1).

Measurement errors for test diameter and total body mass were estimated independently: first from an initial sample of eight urchins that were each measured five times; then 60 additional urchins were measured in the same way, and combined with the first sample to provide data for a second estimate of measurement error. The initial estimates of measurement error are small compared to the values of the sample variances, and the second estimates were even smaller (Table 1).

The effect of accounting for measurement error was slight and had no effect on tests for isometry, common slope, or common elevation of the SMA lines relating demipyramid length and test diameter of the two urchin species (Table 2). Estimates of slope and elevation differed slightly when using the largest estimate of measurement error for test diameter, but the differences were almost indistinguishable when SMA curves were plotted. In conclusion, measurement error was small compared to sample variance, had negligible effect on estimates of slope and elevation, had no qualitative effect on statistical analyses of allometric relationships, and was, therefore, not given further consideration in the interpretation of the relative lantern sizes of $S$. droebachiensis and S. pallidus.
Feeding experiments

The durophagous feeding capacity of $S$. pallidus and S. droebachiensis was estimated in a series of five independently executed experiments involving a total of 186 urchins (Table 3). At the start of each experiment each urchin was placed individually in a $25 \mathrm{~cm}$ diameter glass bowl fitted with a perforated stainless steel collar and a separate supply of running seawater $\left(\approx 7^{\circ} \mathrm{C}\right)$. Each bowl contained 25 mussels, Mytilus edulis, of similar size from one of several non-overlapping size ranges (Table 3). The shell length of all mussels was measured using electronic calipers. The average content of organic matter in the mussels was determined at the start of each experiment from samples of 25 individuals in each size range. The average mussel flesh dry mass of each sample was determined after $\approx 24 \mathrm{~h}$ drying in a $105^{\circ} \mathrm{C}$ oven.

The feeding capacity of each urchin was determined by subtracting the number of intact mussels at the termination of the experiment from the initial number, multiplying by the average mussel flesh dry mass of the appropriate size range, and expressed as the amount of mussel flesh dry mass consumed per day. Unsuccessfully attacked mussels were scored as intact when there was no damage to the

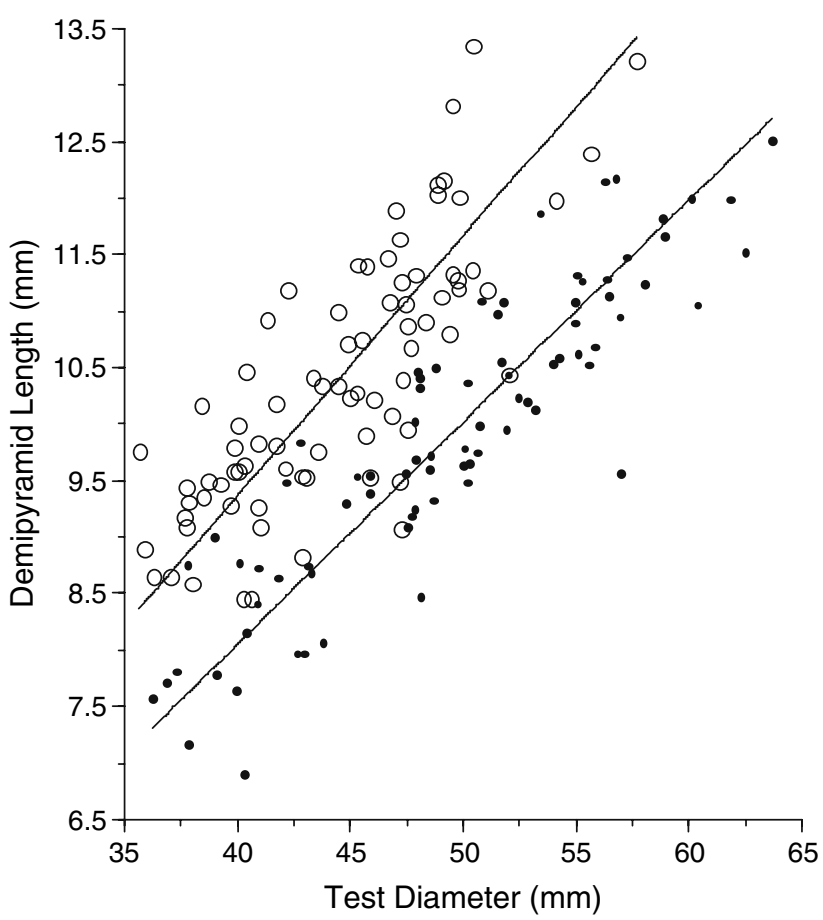

Fig. 1 Allometric relationship between test diameter and demipyramid length of Strongylocentrotus pallidus (large open circles), and S. droebachiensis (small filled circles), from Bodø, Norway 
Fig. 2 Allometric relationships between urchin size (test diameter, wet body mass), and lantern size (wet mass, dry mass, calcite dry mass), of Strongylocentrotus pallidus (large open circles), and $S$. droebachiensis (small filled circles), from Bod $\varnothing$, Norway
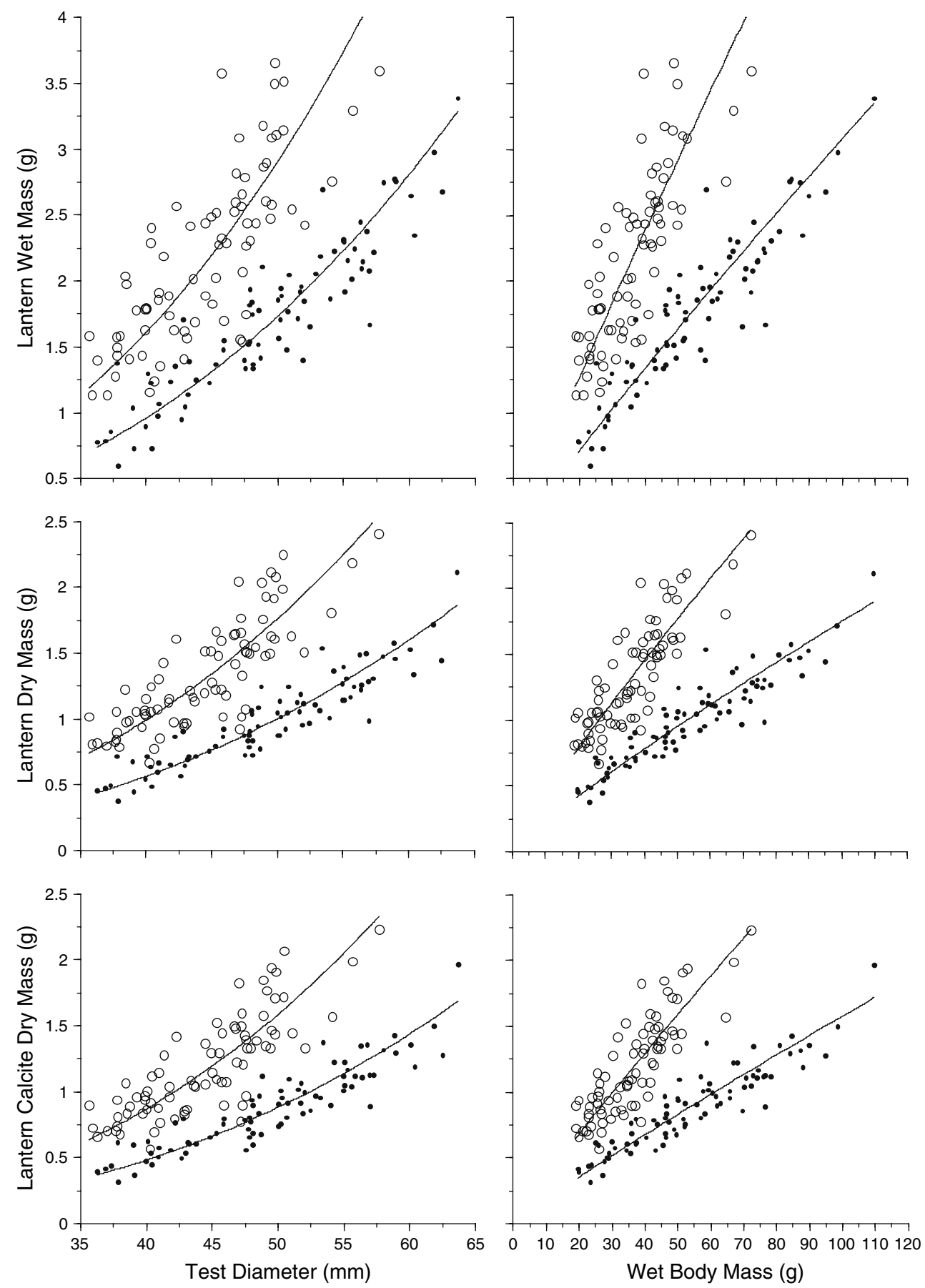

flesh, and rare cases of partially consumed mussels were scored as $50 \%$ intact.

The lantern size of urchins in the feeding experiments was estimated using the allometric relations between test diameter and lantern dry mass established in Table 4. Only two size groups of urchins were used in the feeding experiments (test diameter: small $\approx 40 \mathrm{~mm}$, large $\approx 50 \mathrm{~mm}$, Fig. 4), but lantern sizes fell into three distinct groups: small (small
S. droebachiensis), intermediate (large S. droebachiensis and small S. pallidus), and large (large S. pallidus) (Fig. 4).

Data from the feeding experiments were analysed using graphical methods, i.e. box plots, histograms and percentile comparison plots (Cleveland 1985), because parametric methods were rendered unsuitable by heteroscedasticity that could not be alleviated by data transformation (Sokal and Rohlf 1995). 
Fig. 3 Allometric relationships between urchin size (test diameter, wet body mass), lantern dry mass, and lantern calcite-free dry mass of Strongylocentrotus pallidus (large open circles), and S. droebachiensis (small filled circles), from Bod $\varnothing$, Norway
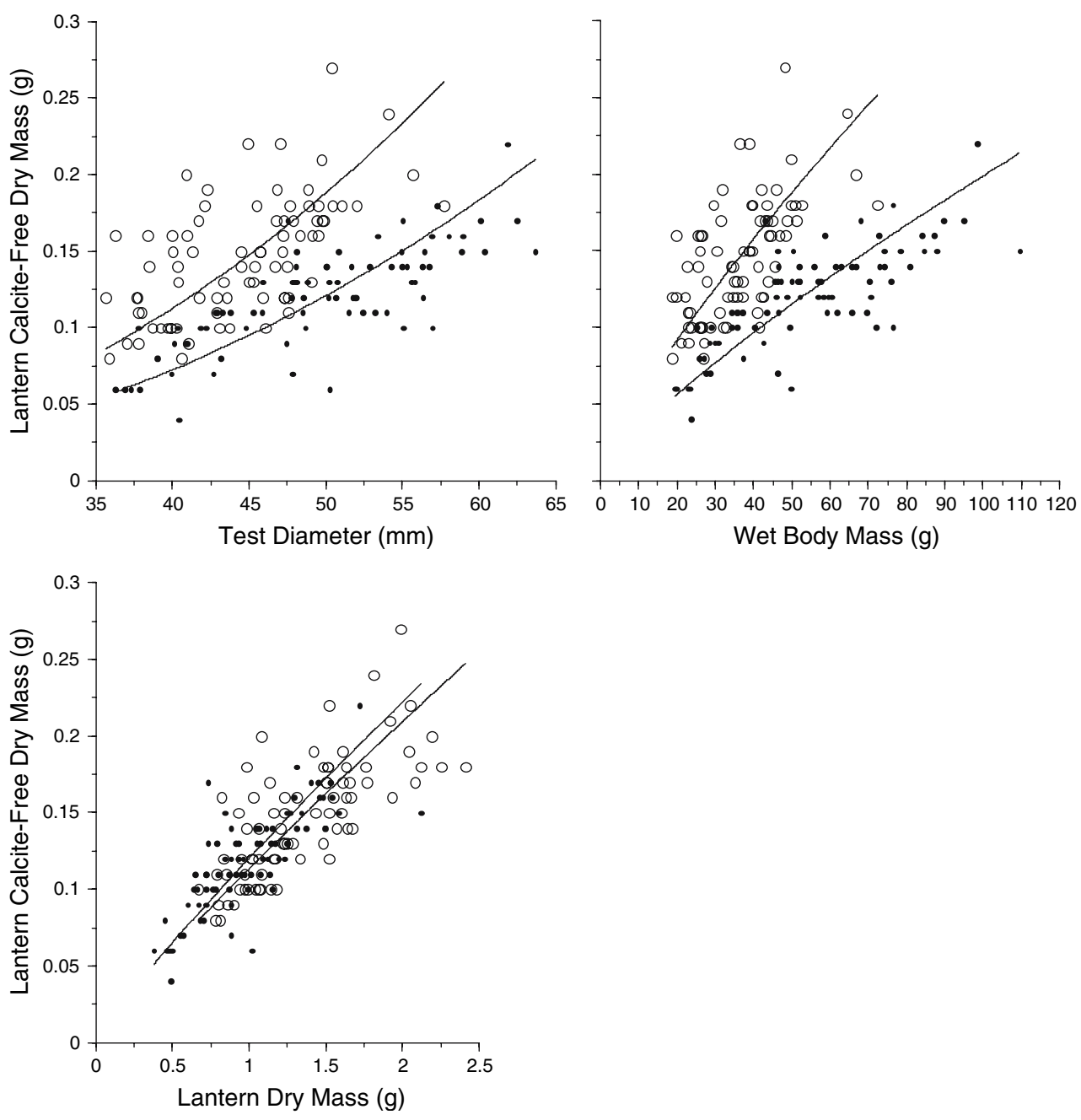

Fig. 4 Box-and-whisker plot comparing test diameter and estimated lantern size of the two size groups of Strongylocentrotus droebachiensis (S.d. shaded boxes, $N=51$ ) and $S$. pallidus (S.p. open boxes, $N=42$ ) used in the feeding experiments. The top, bottom and line through the middle of the plotted boxes represent the 75 th, 25 th, and 50 th percentile (median) respectively. The whiskers extend from the ends of the box to the 10th and 90th percentiles, and the circular symbol is placed on the arithmetic mean
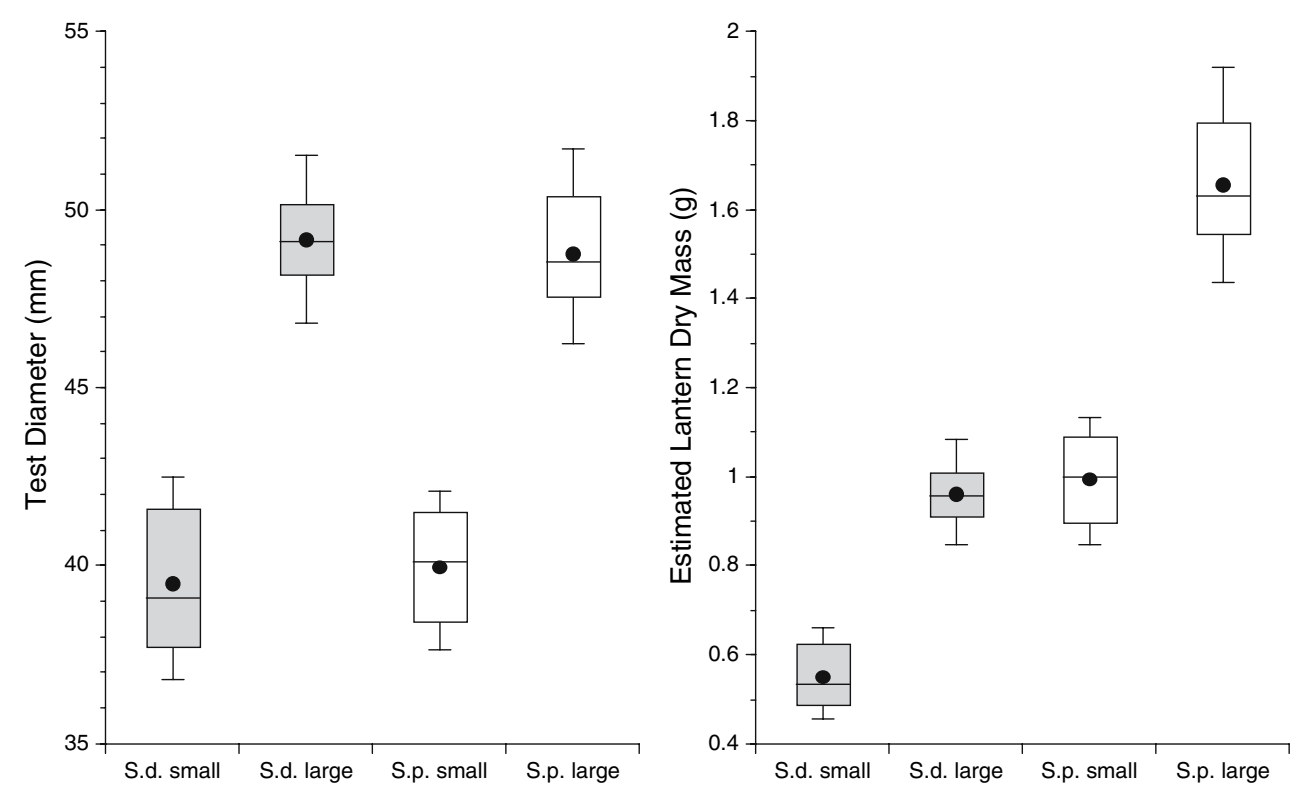


\section{Results}

\section{Lantern Size}

\section{Allometry of test diameter and demipyramid length}

The null hypothesis of isometry of test diameter and demipyramid length, $H_{0}: \beta=1$, could not be rejected for either species $(P \geq 0.05$, Table 2$)$. The test for common slope, $H_{0}: \beta_{S \text {. droebachiensis }}=\beta_{\text {S. pallidus, although super- }}$ fluous when the relationship is isometric, was also non-significant, and the common slope was estimated as $\beta=0.9783$ ( $P \geq 0.05$, Table 2 ). When there is a common slope, the next step in the allometric analysis is to test the null hypothesis of equal elevation, $H_{0}: \ln \left(\alpha_{S \text {. droebachiensis }}\right)=$ $\ln \left(\alpha_{\text {S. pallidus }}\right)$. A significant test result indicates that the lantern sizes of the two species differ by a fixed ratio $\neq 1$, e.g. an $\alpha$-ratio for demipyramid length of 1.16 means that the average demipyramid length of $S$. pallidus is 1.16 times longer than that of a similar sized $S$. droebachiensis $(P<0.001$, Table 2; Fig. 1).

\section{Allometry of test diameter, body mass and lantern mass}

All allometric analyses of the relationship between urchin size (test diameter, wet body mass) and lantern mass (wet mass, dry mass, calcite dry mass and calcite-free dry mass) gave similar results, indicating common slopes and unequal elevations with $S$. pallidus having a heavier Aristotle's lantern than S. droebachiensis (Table 4; Fig. 2). The size differential was $<200 \%$ (i.e. $\alpha$-ratio $<2$ ) for all components of lantern mass.

The estimated $\alpha$-ratio of lantern calcite dry mass (1.91) is larger than the $\alpha$-ratio of calcite-free dry mass (1.63), suggesting that $S$. droebachiensis may have proportionally more organic matter (i.e. muscle tissue, connective tissue and parts of the alimentary canal) in its lantern. However, the $r^{2}$-values for calcite free dry mass for both species were lower than for other components of lantern mass, and a direct analysis of the allometric relationship between lantern dry mass and lantern calcite-free dry mass (Table 4), indicated a common slope and no significant $(P>0.05)$ difference in elevation, i.e. similar amounts of organic matter in the lanterns of both species (Fig. 3).

The amount of variation explained by the allometric analyses is consistently larger for S. droebachiensis (higher $r^{2}$-values, Table 4), indicating that its lantern size was less variable than that of $S$. pallidus.
Effect of enlarged lantern size on durophagous feeding capacity

Urchins with large lanterns (large S. pallidus) consumed approximately four times more mussel flesh dry mass per day than urchins with small lanterns (small S. droebachiensis, Figs. 4, 5). However, urchins with similar, intermediate size lanterns also differed (Figs. 6, 7), with small $S$. pallidus consuming approximately three times more than large S. droebachiensis (Fig. 5). These results indicate that, in addition to and independent of lantern size, there is also a large inter-species effect on the durophagous feeding capacity of these closely related sea urchins.

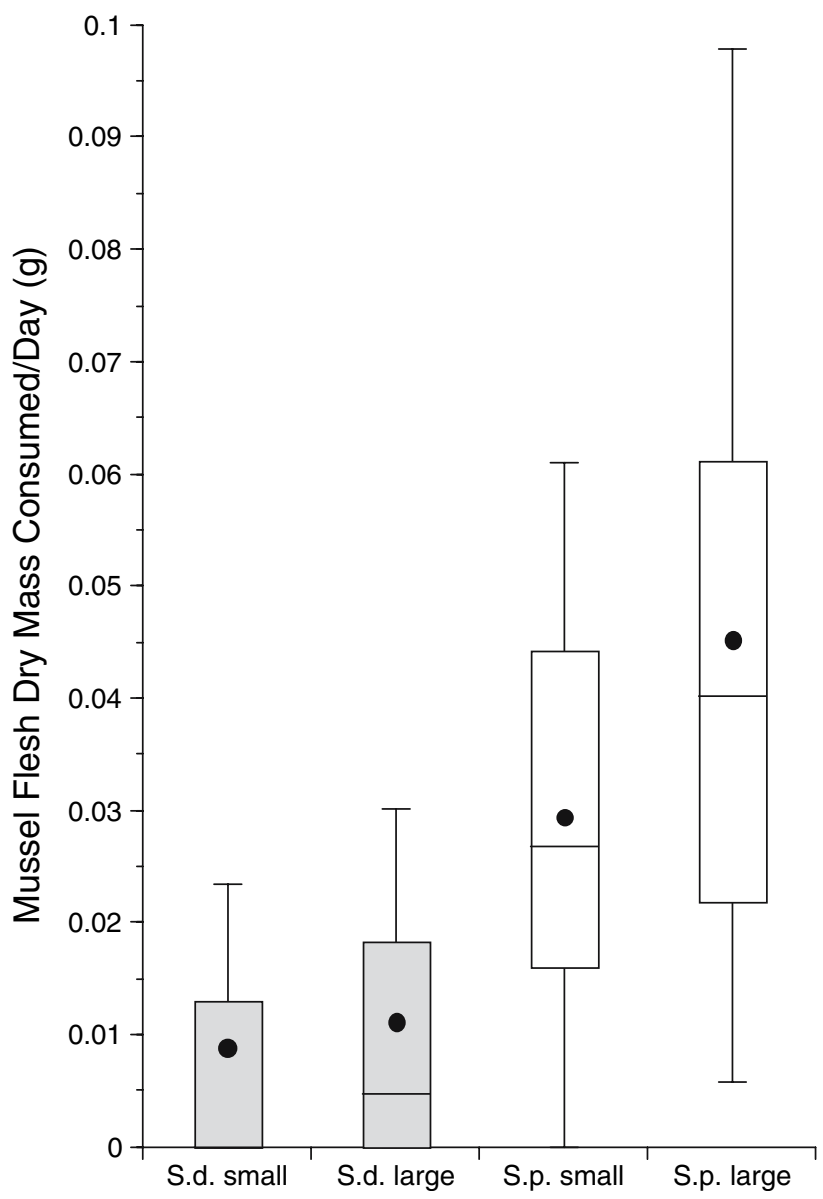

Fig. 5 Box-and-whisker plot comparing durophagous feeding capacity of the two size groups of Strongylocentrotus droebachiensis (S.d. shaded boxes) and S. pallidus (S.p. open boxes) used in the feeding experiments expressed as daily consumption of mussel dry mass. The top, bottom, and line through the middle of the plotted boxes represent the 75th, 25th and 50th percentile (median) respectively. The whiskers extend from the ends of the box to the 10th and 90th percentiles, and the circular symbol is placed on the arithmetic mean 
The percentile plot contrasting small and large $S$. pallidus clearly shows that large urchins with large lanterns consume more mussel dry mass per day than small urchins with intermediate size lanterns (Fig. 7). In comparison, for $S$. droebachiensis there is only a modest effect of increased lantern size, most clearly indicated by a drop from $90 \%$ to $<80 \%$ in the category of lowest consumption $(<0.02 \mathrm{~g}$ mussel flesh dry mass per day), and a corresponding increase in the next category (Fig. 6). These results suggest that $S$. droebachiensis has a limited capacity for durophagy irrespective of lantern size, whereas in S. pallidus the ability to exploit hard shelled prey is positively related to lantern size.

Gonad size

Interestingly, $S$. droebachiensis, the species with the smallest lantern (Fig. 2), had the largest gonads in both field samples (Fig. 8). Gonad mass was variable, but increased rapidly for urchins $>40 \mathrm{~mm}$ in test diameter. The variability was reflected in low coefficients of determination in the allometric analyses relating test diameter and lantern mass to gonad mass $\left(r^{2} \leq 0.55\right.$, Table 5). It was not possible to fit common slopes for both species $(P<0.001)$, and a post hoc multiple comparison of slopes among groups indicated that the steepest slope, i.e. the largest gonads relative to test diameter, were found in $S$. droebachiensis in the February sample from Godøystraumen (Table 5).

Both species had the larger gonad size in the February sample from Godøystraumen according to the allometric analysis of lantern mass and gonad mass (Table 5; Fig. 8). For S. droebachiensis the gonad size in February was approximately 3.2 times larger than in August, and for $S$. pallidus approximately 1.7 times larger.
Fig. 6 Histograms comparing the durophagous feeding capacity of the two size groups of Strongylocentrotus droebachiensis and S. pallidus
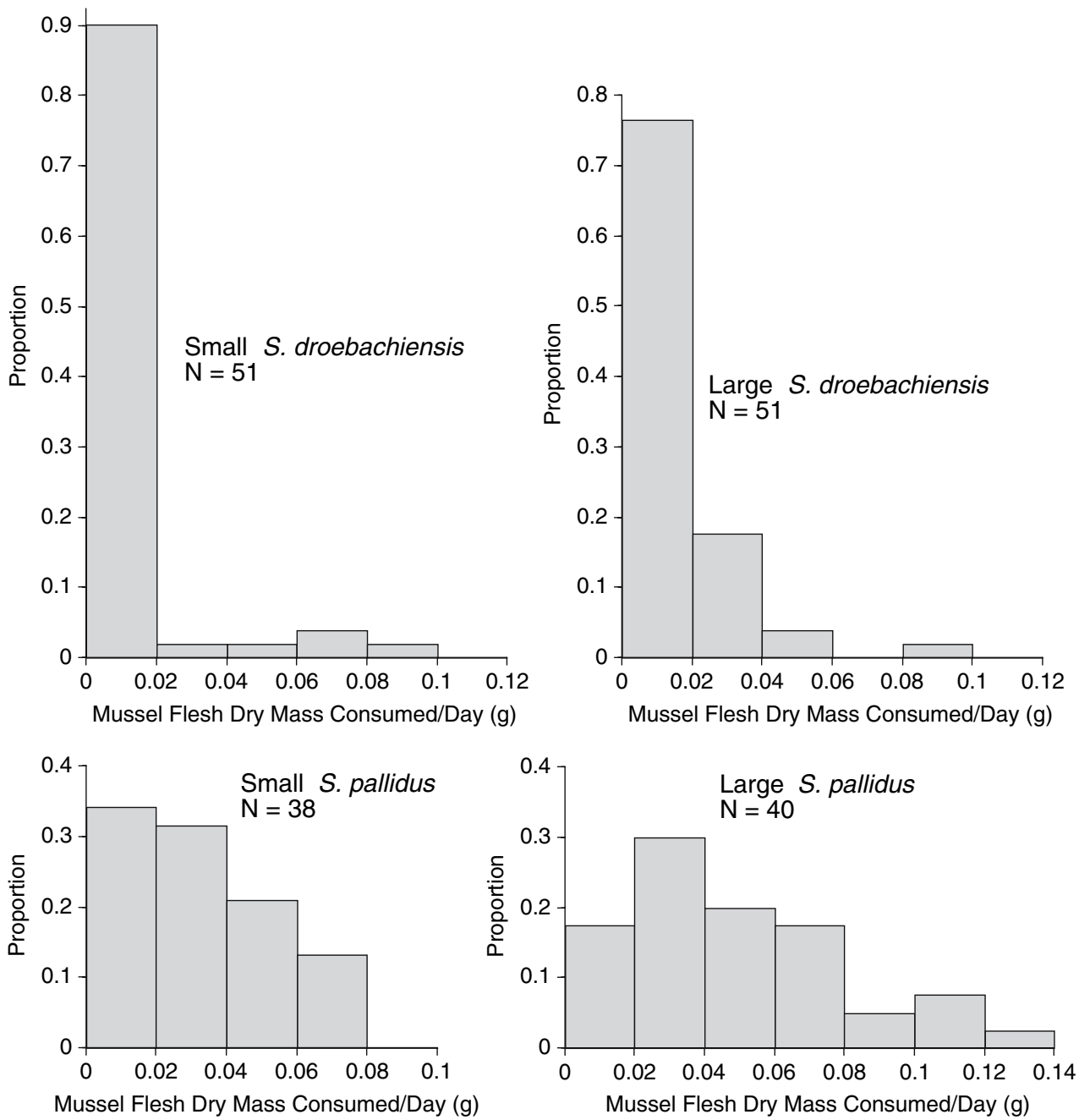

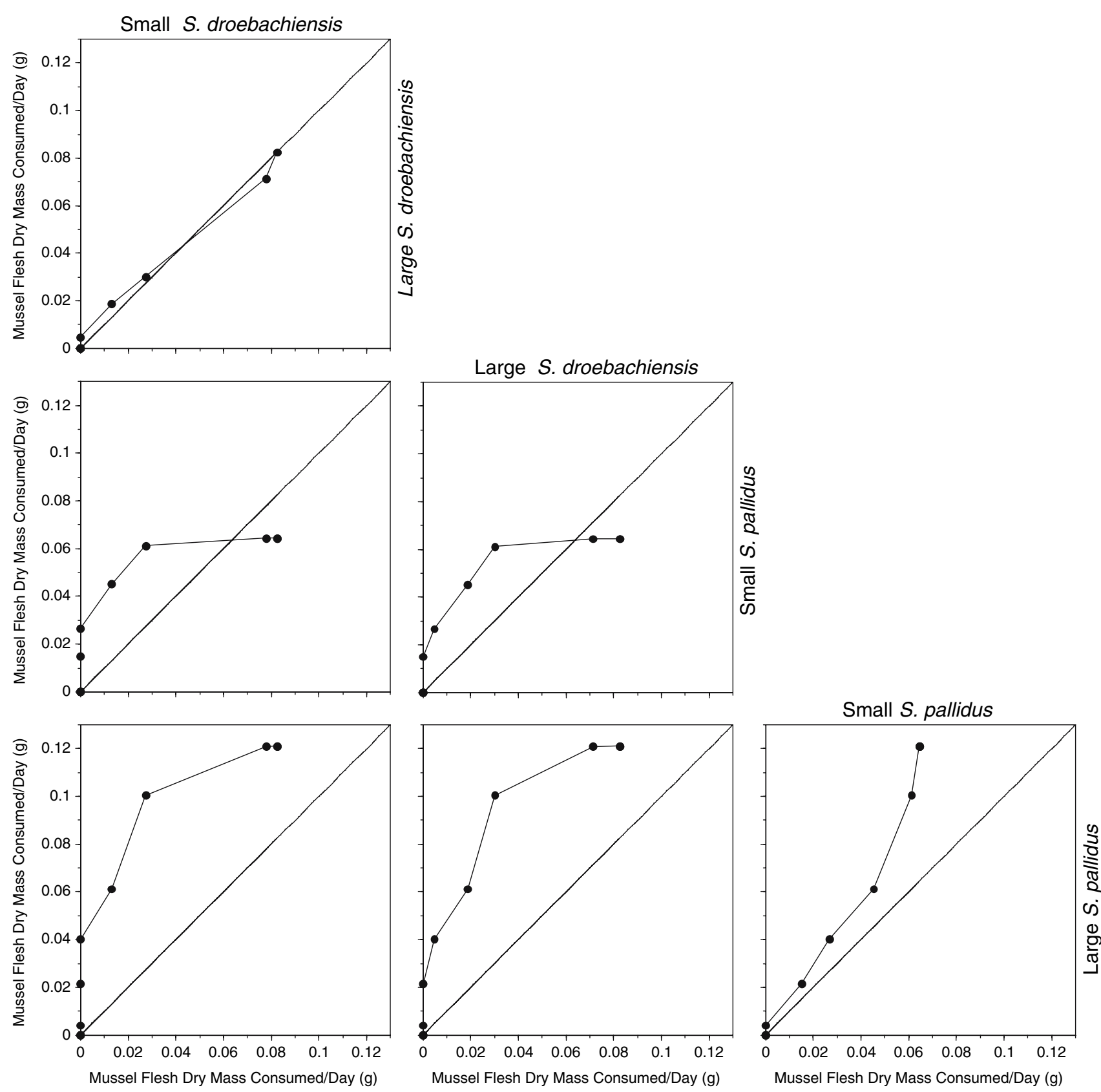

Fig. 7 Percentile plots comparing the durophagous feeding capacity of the two size groups of Strongylocentrotus droebachiensis and S. pallidus. The percentiles compared are $0.5,2.5,10,25,50,75,90,97.5,99.5$ and 100

\section{Discussion}

\section{Enlarged lantern size and durophagy}

Strongylocentrotus pallidus from Bodø, Northern Norway differs from the closely related $S$. droebachiensis by having a larger Aristotle's lantern, and by having a much greater capacity for consuming hard shelled prey. These results are consistent with a hypothesis of enlarged lantern size being a functional specialization for durophagy, and is apparently the first evidence of a relationship between trophic morphology and diet in regular sea urchins. The hypothesis that enlarged lantern size is an adaptation for durophagy is also consistent with studies of sympatric sea urchins from different genera, where the species with the largest lantern occupies microhabitats with a scarcity of soft food (Contreras and Castilla 1987; Fernandez and Boudouresque 1997).

However, contrary to the assumption of a direct relationship between lantern size and feeding capacity in strongylocentrotid sea urchins (Lawrence et al. 1995), there was also a large inter-specific difference in feeding capacity 
Fig. 8 Allometric relationships between size of the Aristotle's lantern, test diameter, and gonad size of Strongylocentrotus pallidus (open circles), and S. droebachiensis (filled circles), from two subtidal sampling locations in Bodø, Norway: Godøystraumen February 2006 (large symbols, upper curve) and Mørkvedbukta August 2006 (small symbols, lower curve)
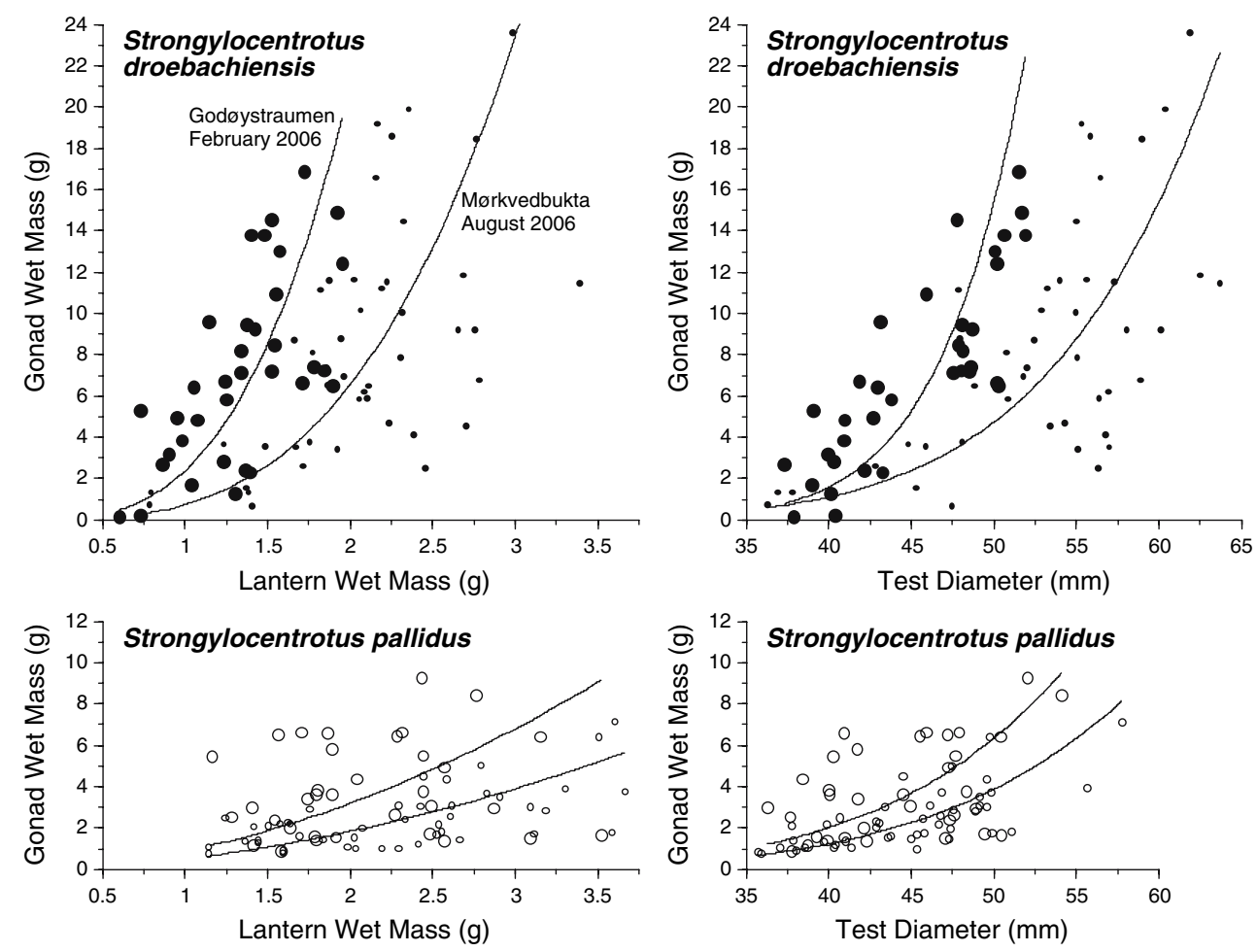

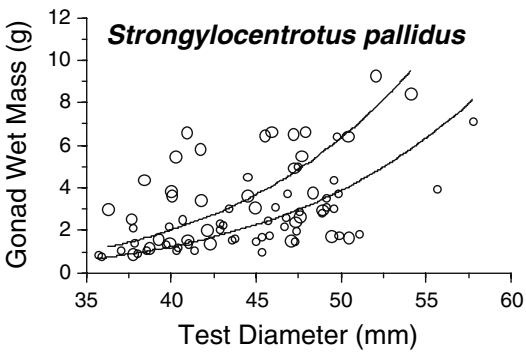

Table 5 Allometric analysis of the relationship between test diameter, size of the Aristotle's lantern and gonad size of Strongylocentrotus pallidus and $S$. droebachiensis, from two subtidal sampling locations in Bodø, Norway

\begin{tabular}{|c|c|c|c|c|c|c|c|}
\hline Group & $N$ & $r^{2}$ & $P$ & $\beta$ & $\operatorname{Ln}(\alpha)$ & $\alpha$ & $\alpha$-ratio \\
\hline \multicolumn{8}{|l|}{$X$ : Test diameter } \\
\hline \multicolumn{8}{|l|}{$Y$ : Gonad wet mass } \\
\hline \multicolumn{8}{|l|}{ S. droebachiensis } \\
\hline Common slope & & & 0.006 & & & & \\
\hline Godøystraumen February 2006 & 35 & 0.546 & 0.000 & $10.175(8.034,12.888)$ & -37.07 & $<10^{-7}$ & \\
\hline Mørkvedbukta August 2006 & 45 & 0.533 & 0.000 & $6.486(5.265,7.991)$ & -23.82 & $<10^{-7}$ & \\
\hline \multicolumn{8}{|l|}{ S. pallidus } \\
\hline Common slope & & & 0.138 & $5.156(4.337,6.137)$ & & & \\
\hline Godøystraumen February 2006 & 34 & 0.166 & & & -18.322 & & 0.61 \\
\hline Mørkvedbukta August 2006 & 45 & 0.550 & & & -18.813 & & 1.63 \\
\hline \multicolumn{8}{|l|}{$X$ : Lantern wet mass } \\
\hline \multicolumn{8}{|l|}{$Y$ : Gonad wet mass } \\
\hline \multicolumn{8}{|l|}{ S. droebachiensis } \\
\hline Common slope & & & 0.199 & $3.143(2.669,3.694)$ & & & \\
\hline Godøystraumen February 2006 & 35 & 0.514 & & & 0.870 & 2.387 & 3.22 \\
\hline Mørkvedbukta August 2006 & 45 & 0.514 & & & -0.298 & 0.742 & 0.31 \\
\hline \multicolumn{8}{|l|}{ S. pallidus } \\
\hline Common slope & & & 0.128 & $1.860(1.518,2.279)$ & & & \\
\hline Godøystraumen February 2006 & 34 & 0.011 & & & -0.126 & 0.882 & 0.57 \\
\hline Mørkvedbukta August 2006 & 45 & 0.357 & & & -0.682 & 0.506 & 1.74 \\
\hline
\end{tabular}

The slope and elevation of the logarithmic allometric equation, $\ln (Y)=\ln (\alpha)+\beta \ln (X)$, were determined using standardized major axis (SMA) estimation. $95 \%$ confidence limits for slope in parentheses

$N$ number of individuals; $r^{2}$ coefficient of determination; $P$ probability value; $\beta$ slope of SMA-line; $\operatorname{Ln}(\alpha)$ intercept of SMA-line; $\alpha$ constant of allometric equation; $\alpha$-ratio multiplicative difference in lantern size when there is a common slope and significant shift in elevation between the two samples 


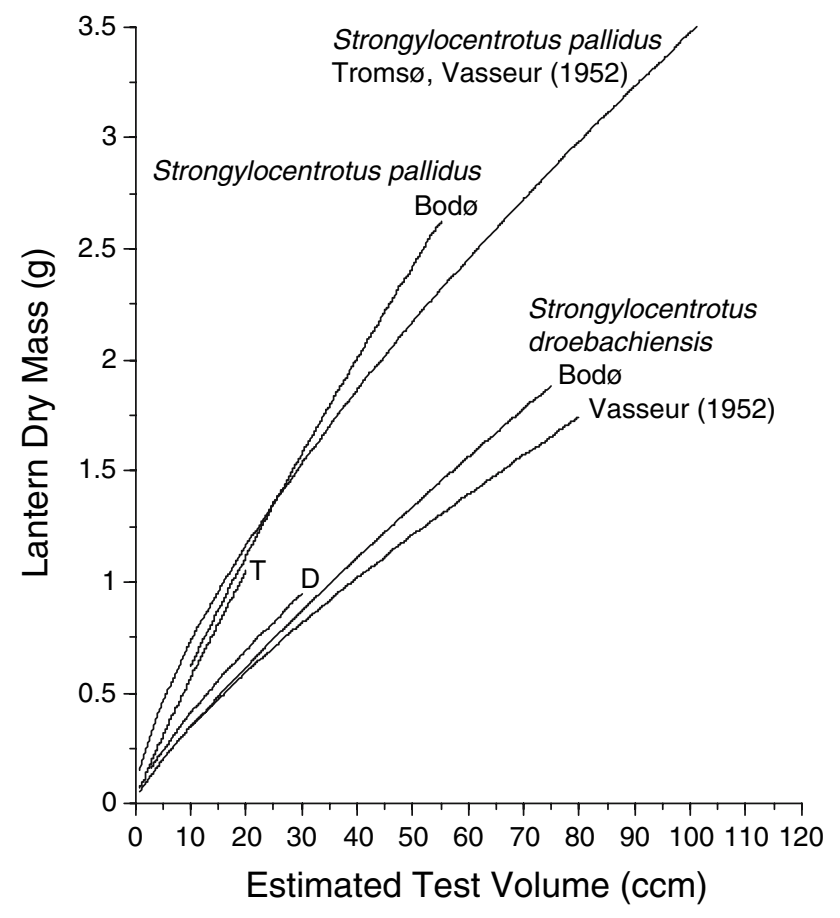

Fig. 9 Back-transformed SMA curves relating estimated test volume and dry mass of the Aristotle's lantern of Strongylocentrotus pallidus and $S$. droebachiensis from Bodø, in comparison with curves estimated from data in Vasseur (1952, Figs. 2, 3, 4). Separate curves are fitted for $S$. pallidus from Troms $\varnothing$, Trondheim $(T)$ and Drøbak $(D)$, and a single curve is fitted for $S$. droebachiensis from the same sites. The length of the curves covers the range of data in each sample

between urchins with similar lantern size, i.e. large $S$. droebachiensis and small $S$. pallidus. The latter result indicates the existence of additional adaptations for durophagy in S. pallidus. Such adaptations would appear to be unrelated to the amount of muscle tissue in the lantern, as there was no significant difference in the amount of organic matter (calcite-free dry mass) in the lanterns of the two species, or to lantern morphology which is also similar (Jensen 1974), but may possibly be related to a diagnostic difference in the number of pore pairs (tube feet), which tend to be larger in $S$. pallidus (Vasseur 1952; Jensen 1974). The functional effect of more tube feet has yet to be investigated, but durophagy may conceivably be facilitated by additional tube feet providing a firmer grip on hard shelled prey to counterbalance the pressure of the working teeth of the lantern.

A superior ability to exploit hard shelled prey provides evidence of adaptive divergence, and may explain the current dominance of $S$. pallidus in northern areas and deep water habitats, where the scarcity of macroalgae might be a greater impediment for $S$. droebachiensis. Field experiments confirm that consumption of intact mussels by $S$. droebachiensis is restricted by their hard shells (Briscoe and Sebens 1988), making a diet of intact mussels inferior to a macroalgal diet despite the fact that mussel flesh alone is a readily consumed, high quality food source in laboratory trials (Thompson 1982, 1984; Meidel and Scheibling 1999).

\section{Latitudinal variation in lantern size}

The results of the present study are in general agreement with earlier observations of enlarged lantern size in S. pallidus (Vasseur 1951, Fig. 3; 1952, Fig. 2; Vader et al. 1986, Fig. 4), but do not support the notion of a geographic trend towards decreased lantern size in southern latitudes as suggested by Vasseur (1952). When comparing the relative lantern sizes of S. pallidus and S. droebachiensis he observed that the Aristotle's lantern of $S$. pallidus was approximately twice the size of $S$. droebachiensis in Troms $\varnothing$, northern Norway, but close to that of S. droebachiensis in Drøbak, southern Norway (the type locality of S. droebachiensis), and of an intermediate size in Trondheim, central Norway, and interpreted his observations as the result of a general trend towards decreased lantern size in southern areas.

I scanned Vasseur's (1952) original figures and used an image analysis program (ImageJ) to obtain an approximate facsimile of his data. However, a general comparison of the alleged size differences is not possible because the SMA curves for S. pallidus from the three sites could not be fitted with a common slope $(P<0.05)$, i.e. the relative difference in lantern size as observed by Vasseur depends on the size of the urchins.

The size of $S$. pallidus in the samples from Trondheim and Drøbak was considerably smaller than in the sample from Troms $\varnothing$, and lack of a common slope means that the curve relating body size and lantern size for $S$. pallidus from Trondheim, although initially below the curve from Troms $\emptyset$ will, if extrapolated intersect and exceed the curve from Troms $\varnothing$ for urchins beyond an estimated test volume of approximately $32 \mathrm{~cm}^{3}$ (Fig. 9). Bodø is located south of Troms $\varnothing$, yet the curve for S. pallidus from Bodø [fitted using Vasseur's formula for estimated test volume $=$ (Diameter ${ }^{2} \times$ Height)/2] also intersects and exceeds the curve from Troms $\varnothing$ beyond an estimated test volume of approximately $25 \mathrm{~cm}^{3}$ (Fig. 9).

Furthermore, Vasseur's (1952) suggestion that the lantern of S. pallidus in Troms $\varnothing$ is approximately twice the size of $S$. droebachiensis is, according to his own data, only valid for urchins with an estimated test volume of $15 \mathrm{~cm}^{3}$. For smaller urchins the difference is $>2$, and for larger urchins the difference is $<2$. For urchins with an estimated test volume of $45 \mathrm{~cm}^{3}$ the difference is 1.81 , the same as the multiplicative size difference ( $\alpha$-ratio) between the two species in Bodø.

Finally, Vasseur (1952) also suggested that there was no geographic variation in the relative lantern size of $S$. droebachiensis from Tromsø, Trondheim and Drøbak. This suggestion is supported by the SMA analysis which 
Fig. 10 Allometric relationships between urchin size and lantern dry mass of Strongylocentrotus droebachiensis (small filled circles), and $S$. pallidus (large open circles), from Bod $\varnothing$, Norway, in comparison with S. droebachiensis (large filled circles with standard deviation error bars) from Kamchatka, Russia (Lawrence et al. 1998)
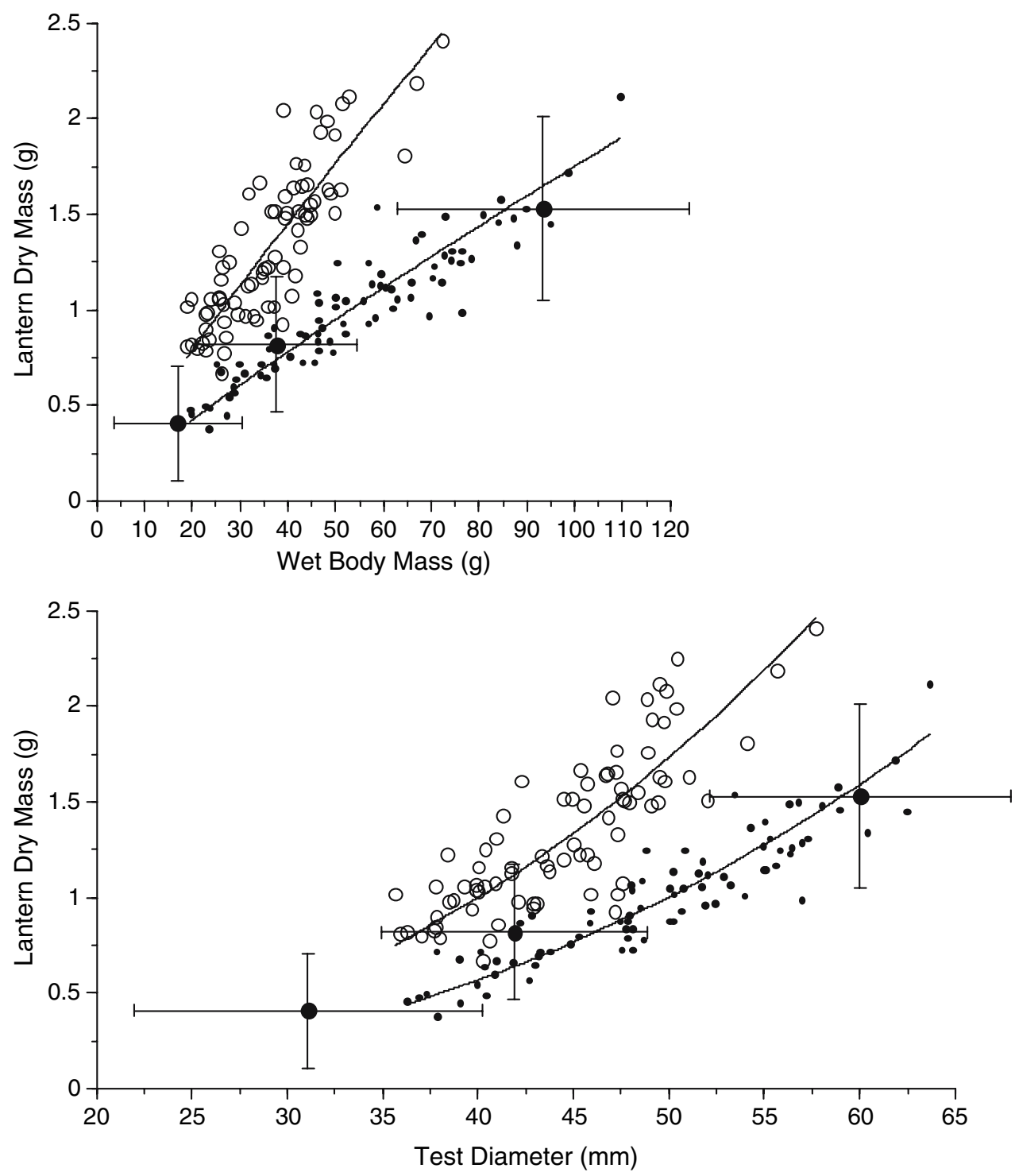

detected no significant, site specific, difference in slope or elevation in his data for $S$. droebachiensis. It is also supported by Lawrence et al. (1998) who found no evidence of habitat related differences in the relative size of the Aristotle's lantern of $S$. droebachiensis from three locations in Kamchatka, Russia. Lawrence et al.'s (1998) observations from Kamchatka appear to fall within the size range of S. droebachiensis from Bodø (Fig. 10).

The lantern size of $S$. droebachiensis from Bodø is similar to Vasseur's (1952) pooled data (Fig. 9), and to Russell's (Russell et al. 1998, 2001) observations from Maine, USA (Fig. 11), for medium sized individuals, but the allometric curves diverge and urchins from Bod $\varnothing$ appear to have larger lanterns at larger body size. However, these differences may at least in part be due to measurement error not being accounted for in the previous publications (c.f. Ebert 2004; Warton et al. 2006).
In conclusion, Vasseur's (1952) notion of systematic geographic variation in the relative lantern size of $S$. pallidus is only tenuously supported by his own sample of small urchins from Drøbak, and should probably be rejected, whereas his notion of similar lantern size of $S$. droebachiensis from different geographical areas is broadly consistent with the available evidence.

Gonad size and lantern size in field populations

S. pallidus had smaller gonads than S. droebachiensis at both sampling locations. Gonad size in sea urchins is a function of two factors: (1) the annual reproductive cycle and (2) food availability. S. pallidus spawns 2-3 months later than $S$. droebachiensis (Vasseur 1952; Falk-Pettersen and Lønning 1983), suggesting that its gonad size was still increasing in 


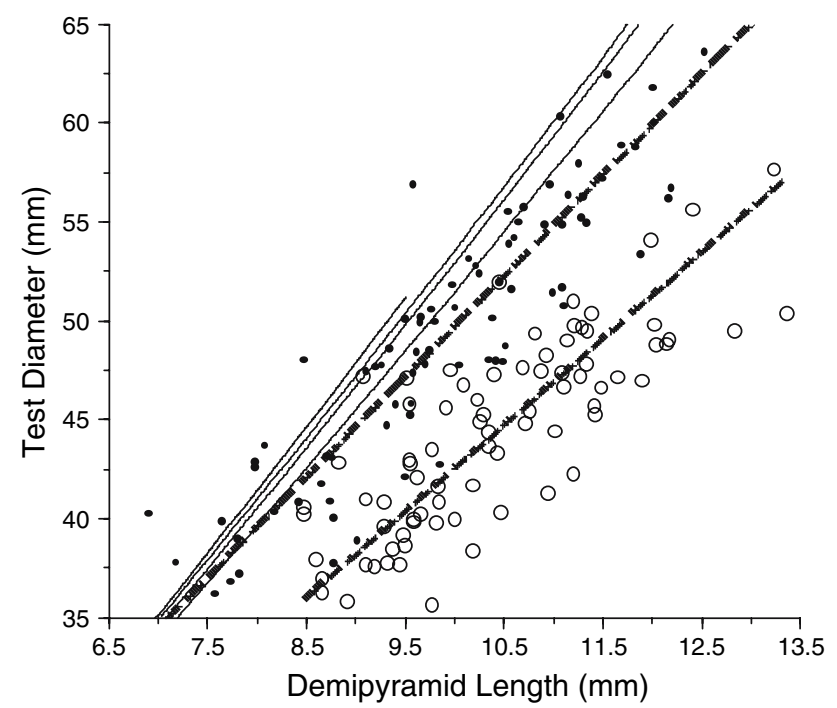

Fig. 11 Allometric relationships between demipyramid length and test diameter of Strongylocentrotus droebachiensis (small filled circles, upper dashed line), and S. pallidus (large open circles, lower dashed line), from Bod $\varnothing$, Norway, in comparison with S. droebachiensis (four thin lines) from Maine, USA (Russell et al. 1998; Russell 2001)

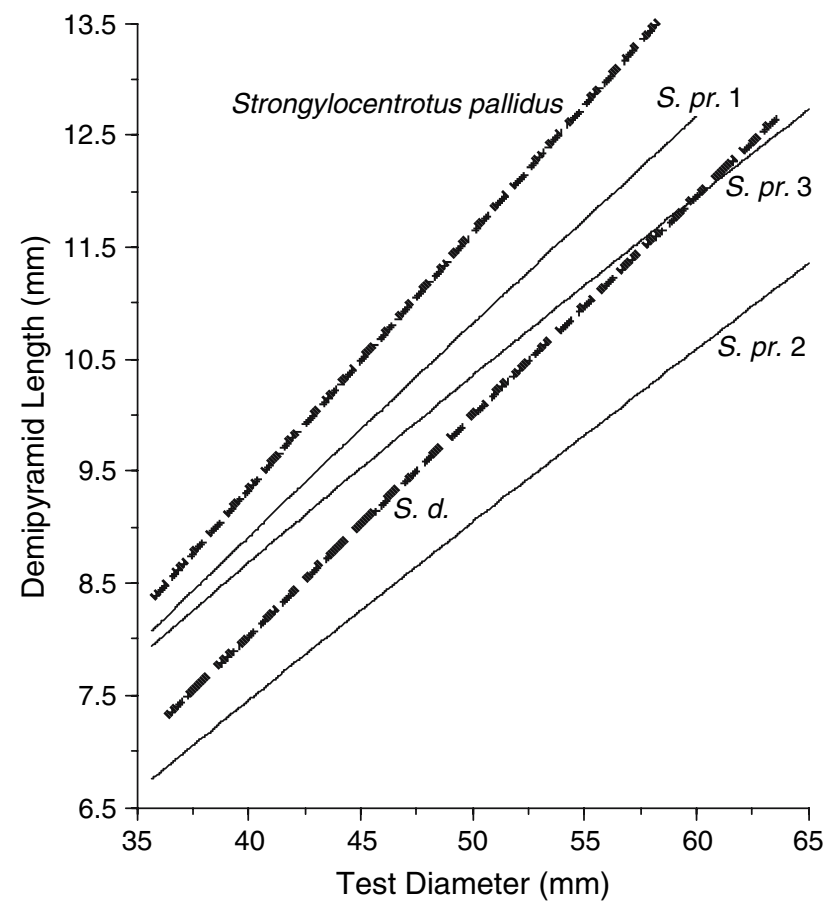

Fig. 12 Allometric relationship between test diameter and demipyramid length of the Aristotle's lantern of Strongylocentrotus pallidus (upper dashed line) and $S$. droebachiensis $(S . d$., lower dashed line) from Bodø, Norway, in comparison with $S$. purpuratus from Oregon (S. pr. 1, 2, Ebert 1980) and California (S. pr. 3, Ebert 1996, Fig. 2)

the February sample, and still close to its annual postspawning minimum in the August sample. The large discrepancy in gonad size between the two species would, nevertheless, suggest that $S$. pallidus was food limited, since
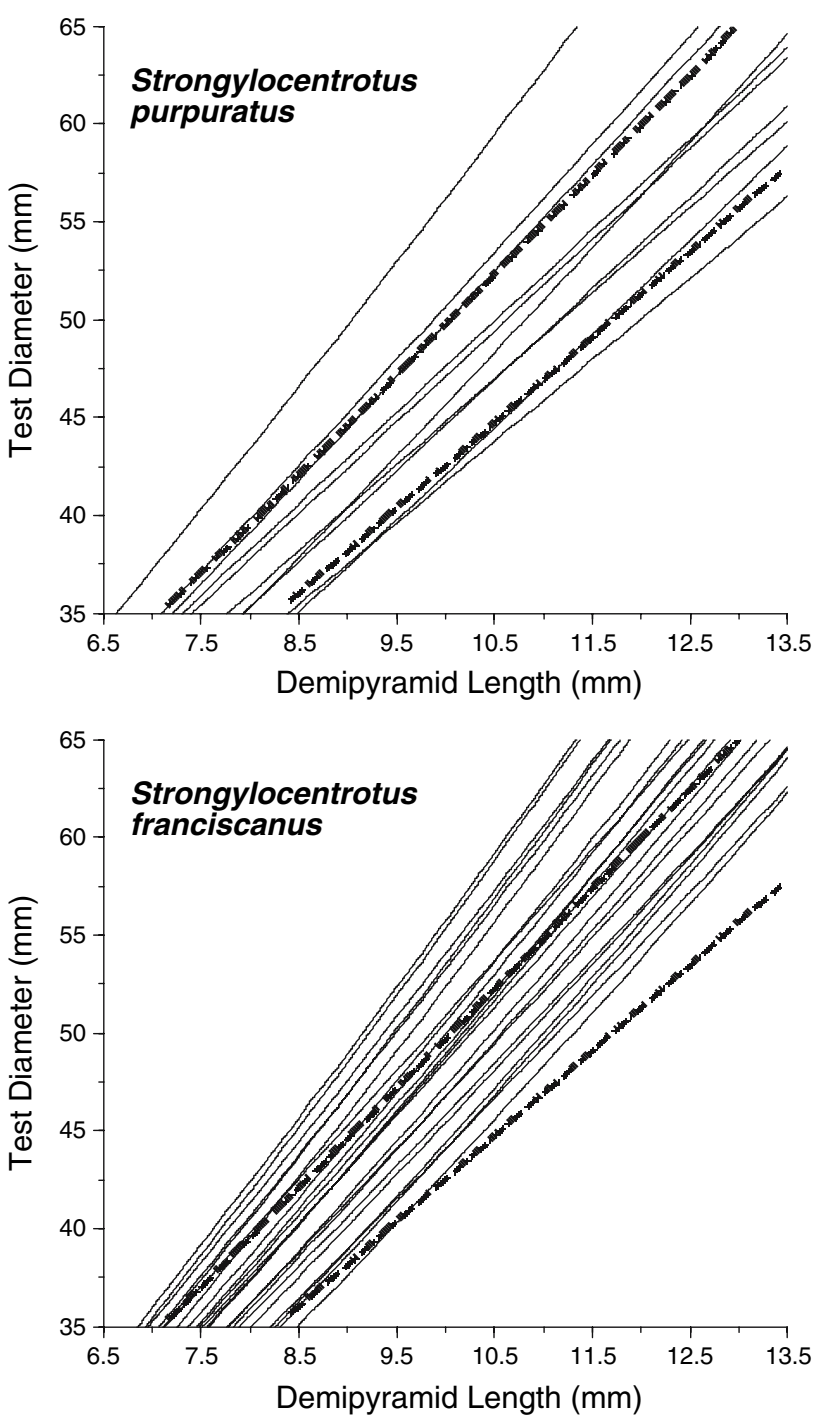

Fig. 13 Allometric relationship between demipyramid length of the Aristotle's lantern and test diameter of Strongylocentrotus pallidus (lower dashed line) and $S$. droebachiensis (upper dashed line) from Bodø, Norway, in comparison with S. purpuratus (Ebert 1980; Russell 1987) and S. franciscanus (Ebert and Russell 1992; Ebert et al. 1999; Rogers-Bennett et al. 2003) from the Northeast Pacific

its gonad size at both sampling sites was similar to the gonad size of $S$. droebachiensis in a food limited barren ground habitat (Hagen 1998). It is possible the food acquisition of $S$. pallidus in these shallow habitats was inhibited by competition from S. droebachiensis (Strathmann 1980), or by environmentally induced microhabitat preferences that may be more successful in deeper habitats.

Durophagy, the ability to efficiently exploit mollusks and other prey with hard exteriors, may be a beneficial trait in deep habitats where $S$. pallidus occurs in conspicuous density and maintains consistent gonad production (Gilkinson et al. 1988; Bluhm et al. 1998; Viktorovskaya and Zuenko 2005), while other Strongylocentrotids, including the deep water species Allocentrotus fragilis (Sumich and 
McCauley 1973), are severely food limited or nonexistent in such habitats. An adaptation for durophagy may also explain relative success of $S$. pallidus in Arctic areas where severely restricted macroalgal vegetation makes seasonally abundant microalgal sediment an important food source (Viktorovskaya and Zuenko 2005), which presumably is more efficiently ingested by an urchin with enlarged lantern size (c.f. Black et al. 1984).

\section{Lantern size of other Strongylocentrotids}

The inter-specific variation in lantern size between $S$. droebachiensis and $S$. pallidus appears to encompass the same range of variation as the reported habitat related phenotypic variation in the lantern size of $S$. purpuratus (Figs. 12, 13) (Ebert 1980; Russell 1987). In contrast, the lantern size of $S$. franciscanus appears to be smaller than the lantern size of $S$. pallidus for urchins larger than $45 \mathrm{~mm}$ in test diameter (Fig. 13). This interpretation is contrary to the suggestion that $S$. franciscanus has a significantly larger lantern than other strongylocentrotid sea urchins (Lawrence et al. 1995), a discrepancy that may be a result of measurement error not being adequately accounted for in previous analyses (c.f. Ebert 2004).

\section{Enlarged lantern size and speciation}

The observed inter-specific differences in durophagy are consistent with a scenario of speciation facilitated by phenotypic accommodation followed by functional adaptation (West-Eberhard 2005; Pigliucci et al. 2006), where the range of phenotypic plasticity in lantern size still exhibited by $S$. purpuratus appears to have been canalized in opposite directions during the divergence of $S$. droebachiensis and $S$. pallidus. The latter species has successfully specialized in durophagy by retaining a large, variable lantern size, supported by a robust, polyporous skeleton, whereas $S$. droebachiensis has evolved a narrower, perhaps less costly, trophic morphology that favours opportunistic, invasive overexploitation of benthic vegetation at the expense of a reduced capacity for durophagy.

In conclusion, the results of this study are consistent with the hypothesis that enlarged lantern size constitutes a functional specialisation for durophagy, and point to the need for more information about the role of lantern size in the trophic ecology of sea urchins.

Acknowledgments Thanks to E. Tryggestad for competent technical assistance, T. Moum and two anonymous referees for critical encouragement, and H.K. Marshall for improving the logical flow and linguistic content of the manuscript. Bodø University College, Norway, generously provided technical assistance, laboratory facilities, and time for manuscript preparation.

Open Access This article is distributed under the terms of the Creative Commons Attribution Noncommercial License which permits any noncommercial use, distribution, and reproduction in any medium, provided the original author(s) and source are credited.

\section{Appendix}

Table 6

Table 6 Literature survey af allometric relationships between lantern size and body size in Strongylocentrotid sea urchins

\begin{tabular}{|c|c|c|c|c|c|c|}
\hline Species & $\operatorname{Ln}(\alpha)$ & $\alpha$ & $\beta$ & Units & Source & Comment \\
\hline \multicolumn{7}{|l|}{$D=\alpha \mathrm{J}^{\beta}$} \\
\hline \multirow[t]{4}{*}{ Strongylocentrotus droebachiensis } & & 3.34 & 1.20 & $\mathrm{~mm}$ & Russell (2001) & Intertidal and Sub 1 \\
\hline & & 3.21 & 1.23 & & & Subtidal 2 \\
\hline & & 3.48 & 1.17 & $\mathrm{~mm}$ & Russell et al. (1998) & Tidepool 1 \\
\hline & & 3.38 & 1.20 & & & Tidepools $2-7$ \\
\hline \multirow[t]{10}{*}{ Strongylocentrotus purpuratus } & & 4.48 & 0.98 & $\mathrm{~cm}$ & Russell (1987) & VI1 \\
\hline & & 4.46 & 1.04 & & & VI2 \\
\hline & & 4.76 & 0.98 & & & VI3 \\
\hline & & 4.71 & 0.99 & & & VI4 \\
\hline & & 4.17 & 1.00 & & & SD1 \\
\hline & & 4.21 & 1.12 & & & $\mathrm{SD} 2$ \\
\hline & & 5.07 & 1.08 & & & PB1 \\
\hline & & 4.98 & 1.08 & & & PB2 \\
\hline & & 4.5667 & 1.155 & $\mathrm{~cm}$ & Ebert (1980) & PZ and EG \\
\hline & & 5.6197 & 1.155 & & & Boulder Field \\
\hline
\end{tabular}


Table 6 continued

\begin{tabular}{|c|c|c|c|c|c|c|}
\hline Species & $\operatorname{Ln}(\alpha)$ & $\alpha$ & $\beta$ & Units & Source & Comment \\
\hline \multirow[t]{22}{*}{ Strongylocentrotus franciscanus } & & 4.4094 & 1.2437 & $\mathrm{~cm}$ & Ebert and Russell (1992) & San Nicolas Island \\
\hline & & 3.31 & 1.15 & $\mathrm{~mm}$ & Rogers-Bennett et al. (2003) & Northern California \\
\hline & & 4.926 & 1.175 & $\mathrm{~cm}$ & Ebert et al (1999; Table 5) & \\
\hline & & 4.852 & 1.145 & & & \\
\hline & & 5.535 & 1.248 & & & \\
\hline & & 5.575 & 1.228 & & & \\
\hline & & 5.352 & 1.248 & & & \\
\hline & & 5.403 & 1.200 & & & \\
\hline & & 4.584 & 1.140 & & & \\
\hline & & 5.329 & 1.212 & & & \\
\hline & & 5.236 & 1.257 & & & \\
\hline & & 4.542 & 1.174 & & & \\
\hline & & 4.292 & 1.241 & & & \\
\hline & & 4.679 & 1.188 & & & \\
\hline & & 5.089 & 1.104 & & & \\
\hline & & 5.059 & 1.209 & & & \\
\hline & & 4.730 & 1.204 & & & \\
\hline & & 4.877 & 1.183 & & & \\
\hline & & 4.441 & 1.244 & & & \\
\hline & & 4.896 & 1.214 & & & \\
\hline & & 4.996 & 1.214 & & & \\
\hline & & 4.409 & 1.168 & & & \\
\hline \multicolumn{7}{|l|}{$J=\alpha D^{\beta}$} \\
\hline \multirow[t]{3}{*}{ Strongylocentrotus purpuratus } & -1.2322 & $(0.2917)$ & 0.7871 & $\mathrm{~cm}$ & Ebert (1996) & Initial sample, Fig. 2 \\
\hline & & 0.2685 & 0.8658 & $\mathrm{~cm}$ & Ebert (1980) & $\mathrm{PZ}$ and $\mathrm{EG}$ \\
\hline & & 0.2245 & 0.8658 & & & Boulder Field \\
\hline \multirow[t]{4}{*}{ Strongylocentrotus franciscanus } & -0.805 & $(0.4471)$ & 0.796 & $\mathrm{~mm}$ & Morris and Campbell (1996) & Wild sample \\
\hline & -0.613 & $(0.5417)$ & 0.735 & & & Starved \\
\hline & -0.723 & $(0.4853)$ & 0.760 & & & Zostera \\
\hline & -1.214 & $(0.2970)$ & 0.866 & & & Nereocystis \\
\hline
\end{tabular}

$D$ test diameter; $J$ demipyramid length; $\operatorname{Ln}(\alpha)$ intercept, $\alpha$ allometric constant, $\beta$ slope of allometric equation. $\alpha$-values in parentheses are converted from $\ln (\alpha)$-values in the source publication

\section{References}

Biermann CH, Kessing BD, Palumbi SR (2003) Phylogeny and development of marine model species: strongylocentrotid sea urchins. Evol Dev 5:360-371

Black R, Codd C, Hebbert D, Vink S, Burt J (1984) The functional significance of the relative size of Aristotle's lantern in the sea urchin Echinometra mathaei (de Blainville). J Exp Marine Biol Ecol 77:81-97

Bluhm BA, Piepenburg D, von Juterzenka K (1998) Distribution, standing stock, growth, mortality and production of Strongylocentrotus pallidus (Echinodermata: Echinoidea) in the northern Barents Sea. Polar Biol 20:325-334

Briscoe CS, Sebens KP (1988) Omnivory in Strongylocentrotus droebachiensis (Müller) (Echinodermata: Echinoidea): predation on subtidal mussels. J Exp Marine Biol Ecol 115:1-24

Chapman ARO, Johnson CR (1990) Disturbance and organization of macroalgal assemblages in the Northwest Atlantic. Hydrobiologia 192:77-121
Cleveland WS (1985) The elements of graphing data. Wadsworth Advanced Books and Software. Monterey

Contreras S, Castilla JC (1987) Feeding behaviour and morphological adaptations in two sympatric sea urchin species in central Chile. Marine Ecol Prog Ser 38:217-224

Dayal S, Kiyama T, Villinski JT, Zhang N, Liang S, Klein WH (2004) Creation of cis-regulatory elements during sea urchin evolution by co-option and optimization of a repetitive sequence adjacent to the spec2a gene. Dev Biol 273:436-453

De Ridder C, Lawrence JM (1982) Food and feeding mechanisms: Echinoidea. In: Jangoux M, Lawrence JM (eds) Echinoderm nutrition. Balkema, Rotterdam, pp 57-115

Ebert TA (1980) Relative growth of sea urchin jaws: an example of plastic resource allocation. Bull Marine Sci 30:467-474

Ebert TA (1988) Allometry, design and constraint of body components and of shape in sea urchins. J Nat Hist 22:1407-1425

Ebert TA (1996) Adaptive aspects of phenotypic plasticity in echinoderms. Oceanol Acta 19:347-355 
Ebert TA (2004) Shrinking sea urchins and the problems of measurement. In: Heinzeller T, Nebelsick J (eds) Echinoderms: München. Taylor \& Francis, London, pp 321-325

Ebert TA, Dixon JD, Schroeter SC, Kalvass PE, Richmond NT, Bradbury WA, Woodby DA (1999) Growth and mortality of red sea urchins Strongylocentrotus franciscanus across a latitudinal gradient. Marine Ecol Prog Ser 190:189-209

Ebert TA, Russell MP (1992) Growth and mortality estimates for red sea urchin Strongylocentrotus franciscanus from San Nicolas Island, California. Marine Ecol Prog Ser 81:31-41

Edwards PB, Ebert TA (1991) Plastic responses to limited food availability and spine damage in the sea urchin Strongylocentrotus purpuratus (Stimpson). J Exp Marine Biol Ecol 145:205-220

Estes JA, Steinberg PD (1988) Predation, herbivory, and kelp evolution. Paelobiology 14:19-36

Falk-Pettersen I-B, Lønning S (1983) Reproductive cycles of two closely related sea urchin species, Strongylocentrotus droebachiensis (O.F. Müller) and Strongylocentrotus pallidus (G.O. Sars). Sarsia 68:157-164

Falster DS, Warton DI, Wright IJ (2006) SMATR: standardised major axis tests and routines, ver. 2.0

Fernandez C, Boudouresque C-F (1997) Phenotypic plasticity of Paracentrotus lividus (Echinodermata: Echinoidea) in a lagoonal environment. Marine Ecol Prog Ser 152:145-154

Gagnon J-M, Gilkinson KD (1994) Discrimination and distribution of the sea urchins Strongylocentrotus droebachiensis (O.F. Müller) and S. pallidus (G.O. Sars) in the Northwest Atlantic. Sarsia 79:1-11

Gilkinson KD, Gagnon J-M, Schneider DC (1988) The sea urchin Strongylocentrotus pallidus (G.O. Sars) on the Grand Bank of Newfoundland. In: Burke RD, Mladenov PV, Lambert P, Parsley RL (eds) Echinoderm biology. Proceedings of the 6th international echinoderm conference, Victoria. Balkema, Rotterdam, pp $467-473$

Hagen NT (1983) Destructive grazing of kelp beds by sea urchins in Vestfjorden, northern Norway. Sarsia 68:177-190

Hagen NT (1987) Sea urchin outbreaks and nematode epizootics in Vestfjorden, northern Norway. Sarsia 72:213-229

Hagen NT (1998) Effect of food availability and body size on out-ofseason gonad yield in the green sea urchin, Strongylocentrotus droebachiensis. J Shellfish Res 17:1533-1539

Harrold C, Pearse JS (1987) The ecological role of echinoderms in kelp forests. Echinoderm Stud 2:137-233

Jensen M (1974) The Strongylocentrotidae (Echinoidea), a morphologic and systematic study. Sarsia 57:113-148

Lawrence JM (1975) On the relationships between marine plants and sea urchins. Oceanogr Marine Biol Ann Rev 13:213-286

Lawrence JM (1987) A functional biology of echinoderms. Croom Helm, London

Lawrence JM, Robbins BD, Bell SS (1995) Scaling of the pieces of the Aristotle's lantern in five species of Strongylocentrotus (Echinodermata: Echinoidea). J Nat History 29:243-247

Lawrence JM, Robbins BR, Bazhin A (1998) Phenotypic plasticity in Strongylocentrotus droebachiensis (Echinodermata: Echinoidea) at Petropavlovsk-Kamchatsky, Russia. In: Mooi R, Telford M (eds) Echinoderms: San Francisco. Balkema, Rotterdam, pp 725-728

Lee Y-H (2003) Molecular phylogenies and divergence times of sea urchin species of Strongylocentrotidae, Echinoidea. Mol Biol Evol 20:1211-1221

Marincovich L, Gladenkov AY (1999) Evidence for the age of Bering Strait. Quat Sci Rev 20:329-335

Meidel SK, Scheibling RE (1999) Effects of food type and ration on the reproductive maturation and growth of the sea urchin Strongylocentrotus droebachiensis. Mar Biol 134:155-166
Morris TJ, Campbell A (1996) Growth of juvenile red sea urchins (Strongylocentrotus franciscanus) fed Zostera marina or Nereocystis luetkeana. J Shellfish Res 15:777-780

Palumbi SR, Kessing BD (1991) Population biology of the transArctic exchange: MtDNA sequence similarity between Pacific and Atlantic sea urchins. Evolution 45:1790-1805

Pigliucci M, Murren CJ, Schlichting CD (2006) Phenotypic plasticity and evolution by genetic assimilation. J Exp Biol 209:23622367

Reiss MJ (1991) The allometry of growth and reproduction. Cambridge University Press, Cambridge

Ricker WE (1984) Computation and uses of central trend lines. Can J Zool 62:1897-1905

Rogers-Bennett L, Rogers DW, Bennett WA, Ebert TA (2003) Modeling red sea urchin (Strongylocentrotus franciscanus) growth using six growth functions. Fish Bull US 101:614-626

Russell MP (1987) Life history traits and resource allocation in the purple sea urchin Strongylocentrotus purpuratus (Stimpson). J Exp Marine Biol Ecol 108:199-216

Russell MP (2001) Spatial and temporal variation in growth of the green sea urchin, Strongylocentrotus droebachiensis, in the Gulf of Maine, USA. In: Barker MF (ed) Echinoderms 2000. Swets \& Zeitlinger, Lisse, pp 533-537

Russell MP, Ebert TA, Petraitis PS (1998) Field estimates of growth and mortality of the green sea urchin, Strongylocentrotus droebachiensis. Ophelia 48:137-153

Scheibling RE, Hatcher BG (2007) Ecology of Strongylocentrotus droebachiensis. In: Lawrence JM (ed) Edible sea urchins: biology and ecology. Elsevier, Amsterdam, pp 354-392

Sokal RR, Rohlf FJ (1995) Biometry. The principles and practice of statistics in biological research. W.H. Freeman, San Francisco

Strathmann RR (1980) On hybridization and competition between Strongylocentrotus droebachiensis and Strongylocentrotus pallidus. In: Jangoux M (ed) Echinoderms: present and past. Balkema, Rotterdam, pp 413

Sumich JL, McCauley JE (1973) Growth of a sea urchin, Allocentrotus fragilis, off the Oregon coast. Pacific Sci 27:56-167

Swan EF (1962) Evidence suggesting the existence of two species of Strongylocentrotus (Echinoidea) in the northwest Atlantic. Can J Zool 40:1211-1222

Thompson RJ (1982) The relationship between food ration and reproductive effort in the green sea urchin, Strongylocentrotus droebachiensis. Oecologia (Berl.) 56:50-57

Thompson RJ (1984) Partitioning of energy between growth and reproduction in three populations of the sea urchin Strongylocentrotus droebachiensis. In: Engels W (ed) Advances in invertebrate reproduction, vol 3. Elsevier, Amsterdam, pp 425-432

Vader W, Hagedal Pedersen BS, Lönning S (1986) Morphological differences between two closely related sea urchin species, Strongylocentrotus droebachiensis and S. pallidus, in northern Norway (Echinodermata, Echinoidea). Fauna Norw Ser A 7:10_ 14

Vasseur E (1951) Strongylocentrotus pallidus (G.O. Sars) and S. droebachiensis (O.F. Müller) distinguished by means of spermagglutination with egg-water and ordinary morphological characters. Acta Borealia A Scientia 2:1-16

Vasseur E (1952) Geographic variation in the Norwegian sea-urchins, Strongylocentrotus droebachiensis and S. pallidus. Evolution 6:87-100

Vermeij GJ (1991) Anatomy of an invasion: the trans-Arctic interchange. Paleobiology 17:281-307

Vermeij GJ (1992) Time of origin and biogeographical history of specialized relationships between northern marine plants and herbivorous molluscs. Evolution 46:657-664 
Viktorovskaya GI, Zuenko YI (2005) The impact of environmental conditions on the reproduction of the sea urchin Strongylocentrotus pallidus (Sars) off the Primor'e coast, Japan Sea. Oceanology 45:76-84

Warton DI, Wright IJ, Falster DS, Westoby M (2006) Bivariate linefitting methods for allometry. Biol Rev 81:259-291
West-Eberhard MJ (2005) Phenotypic accommodation: adaptive innovation due to developmental plasticity. J Exp Zool B-Mol Dev Evol 304B:610-618 